\title{
Erdemli Bir Mal Olarak Kan ve Kök Hücre Bağışı Yapan Gerçek Kişilere Vergi İndirimi Sağlanması"
} (Araştırma Makalesi)

\author{
Providing Tax Reduction to Real Persons Donating Blood and Stem Cells as \\ a Merit Goods
}

Doi: 10.29023/alanyaakademik.680620

\author{
Alparslan UĞUR \\ Doç. Dr. Kırıkkale Üniversitesi İktisadi ve İdari Bilimler Fakültesi Maliye Bölümü, \\ alparslanugur@hotmail.com \\ Orcid No:0000 000188811745
}

Bu makaleye atıfta bulunmak için: Ŭ̆ur A. (2020). Erdemli Bir Mal Olarak Kan ve Kök Hücre Bă̆lşı Yapan Gerçek Kişilere Vergi İndirimi Sağlanması, Alanya Akademik Bakış, 4(2), Sayfa No. 369-380.

\author{
Anahtar kelimeler: \\ Sağlık, Teşvik, Vergi \\ Indirimi \\ Makale Geliş Tarihi: \\ 27.01.2020 \\ Kabul Tarihi: \\ 28.04.2020
}

\section{Keywords:}

Health, Incentive, Tax Deduction

\section{ÖZET}

$\overline{\text { Kan ve kök hücre bağışı, yapıldı ̆̆ında birçok kişinin hayatını kurtararak }}$ önemli faydalar sağlayan fakat genelde insanların yapmadığl/yapamadĭ̆ erdemli mallar grubunda yer almaktadır. Bütün ülkelerde kan ve kök hücre bağışının özendirilmesi konusunda devletler önemli görevler üstlenmektedir. Başta kamu spotları olmak üzere farklı teşvik ve yönlendirmeler söz konusudur. Çalışma kan ve kök hücre bağışının artırılması konusunda alternatif bir öneri getirmektedir. Buna göre çalışmanın amacı, ülkemizde senede $3 \mathrm{kez}$ kan bağışı yapan gerçek kişilere ilgili yıldaki toplam kazançlarının \%5'ini, kök hücre bağış̧̧ıs olan ve HLA ${ }^{1}$ doku tipinin uyuşması sonucu kök hücre naklini gerçekleştiren gerçek kişilere ilgili yıldaki toplam kazançlarının \%30'unu gider olarak düşülmesini ve bu sayede de kan ve kök hücre bağışının teşvik edilmesini sağlamaktır.

\begin{abstract}
Blood and stem cell donation take place in the merit goods group that provides important benefits by saving the life of a lot of people but people generally don't/can't do it. In all countries, state institutions assume important roles to encourage blood and stem cell donations. There are different encouragements and orientations, like especially, public service announcements. This study brings forward an alternative proposal for increasing blood and stem cell donations. This study aims to make it possible that $5 \%$ of total annual income of real persons who donate blood 3
\end{abstract}

\footnotetext{
* Bu çalışma 25-29 Ekim 2019 tarihleri arasında Antalya'da VI. International Strategic Research Congress'de sunulan ve özet olarak yayınlanan "Erdemli Bir Mal Olarak Kan Bağışı Yapan Gerçek Kişilere Vergi İndirimi Sağlanması" adlı çalışmanın geliştirilmiş ve güncelleştirilmiş halidir.

${ }^{1}$ HLA sistemi, Human Leucocyte Antigen (insan lökosit antijeni) kelimelerinin kısaltmasıdır ve bağışıklık sisteminin kendinden olmayanı tanımasını sağlamaktadır. Hasta ve bağış̧̧ının (alıcı ve verici) kan hücre naklinde uyumlu olup olmadığını anlamak için HLA'ya (doku alerjenlerine) bakılmaktadır. Doku uyumunun alıcı ve verici arasında yüksek olması nakilin başarı şansını artırmaktadır (Kemik İliği Transplantasyonu, 2019).
} 
times a year is deduced and $30 \%$ of annual income of real persons who donate stem cells and who perform stem cell transplantation as their HLA tissue type matches is deduced as expenses, and therefore; to encourage of blood and stem cell donation.

\section{GİRIŞ}

Erdemli mallar, toplumun sağlığı açısından çok önemli olduğu halde eğitim, bilgi ve gelir yetersizlikleri gibi sebepler yüzünden yetersiz talebin olduğu mal ve hizmetlerdir. Bütün toplumlarda kan ve kök hücre bağışı çok önemli erdemli bir davranış olarak görülürken farklı nedenlerle bağış uygulamasını birçok kişi eksik yapmakta ya da hiç yapmamaktadır. Günümüzde kan, kaynağı sadece insan olan ve elde edilmesinde başkaca hiçbir alternatifin bulunmadığı yegane tedavi aracıdır. Teknolojik imkanlar son yıllarda hızla artsa da kanın yerini alabilecek başkaca etken bir madde halen söz konusu değildir. Birçok tedavi ve ameliyatta kan ihtiyacı olmazsa olmaz yaşamsal öneme sahiptir. Kan bağışı gerek var olan ihtiyaçların giderilmesi gerekse de kök hücre donörü bulunması kapsamında uygulanan TÜRKÖK ${ }^{2}$ programı için elzemdir. Kök hücreler, belli hücrelere dönüşebilen ve kendini yenileme yeteneği olan hücrelerdir. Vücudumuzdaki hücrelerin birçoğunun kendini yenileme yeteneği çok zayıftır ve bu hücreler farklılaşmıştır. Kök hücre tedavisi birçok hastalığın nihai ve tek çaresidir. Ülkemizde 2018 yılı verilerine göre toplam 2.571 .482 ünite kan bağış1 yapılmış ve bunun \%57'si düzenli bağışçılardan sağlanmıştır. Düzenli bağışçıların toplam nüfus içindeki oranı yaklaşık \%1,8 düzeylerindedir. Düzenli bağışçıların gelişmiş ülkelerdeki toplam nüfus içindeki oranı yaklaşık \%5'ler düzeyindedir. 2018 yılında 129,704 kök hücre bağışçısı kazanılmış, bu da toplam nüfusun on binde 15,81'i düzeylerindedir. Bu çalışmada erdemli bir mal olarak kan ve kök hücre bağışının önemi anlatılarak, ülkemizdeki kan ve kök hücre bağışının eksikliği vurgulanacak ve ekstra-fiskal bir amaç olarak vergilemeyle çok sayıda insanın hayatını kurtaracak bağışların teşviki için alternatif bir öneri getirilecektir.

\section{ERDEMLİ MAL KAVRAMI}

Erdemli mal kavramını ilk defa kullanan Musgrave'e göre erdemli mallar, yeterli eğitim ve bilgi düzeyinin olmaması gibi nedenlerle halkın sağlığı açısından gerekli olmasına karşılık talebi yetersiz olan mal ve hizmetlerdir (Kirmanoğlu, 2017:124). Buna göre sahip olduğu pozitif dışsallıklara rağmen faydalarının yeterli düzeyde anlaşılmaması/algılanmaması sebebiyle üretimi piyasa şartlarına bırakıldığında eksik üretilip tüketilen mal ve hizmetler bu gruba girmektedir (Durmuş, 2006:72). Erdemli mallardaki tercih çarpıklığının en önemli nedeni bireylerdeki bilgi ve gelir yetersizlikleri, bireylerin fayda-maliyet analizleri yapamamaları ve akılcı olmayan davranışlar sergilemeleridir. Özellikle düşük ve orta kalkınmışlık düzeyinde gelirin adaletsiz dağıtıldığı yoksul ülkelerde devletin bu alanlardaki

\footnotetext{
21 Nisan 2015 tarihinde kurulan TÜRKÖK Ulusal Kemik İliği Bankası, kemik iliğine ihtiyacı olan adayları en kısa zamanda bulmak, özellikle kemik iliği nakli yapılmadan önce yapılırken ve yapıldıktan sonra üçüncü kişi ve taraflarla koordinasyonu sağlamak amacıyla çalışma yürütmektedir. TÜRKÖK günümüzde uluslararası üyelikleriyle uluslararası standartlarda çalışma yürüten bir merkez haline gelmiştir (T.C. Sağlık Bakanlığı, 2019). 370
} 
rolü başattır. Erdemli mallara olan talep yetersizliğini gidermenin 3 yolu bulunmaktadır (Kirmanoğlu, 2017:124):

- Zorlayıcılık: Devletin bu hizmetlerin alınmasını zorunlu kılması (Örn: temel eğitim).

- Kişilere var olan riskleri göstererek bilgi edinmeyi kolaylaştırması.

- Sübvansiyon yapmak: Fiyatın üzerine sübvansiyon yaparak var olan talep düzeyini artırmak.

\section{ERDEMLI BİR MAL OLARAK KAN VE KÖK HÜCRE BAĞIŞININ ÖNEMI}

En eski uygarlıklardan bu yana kan insana güç veren, onu hayatta tutan yegane güç olarak görülmüştür. Kan banyosu Eski Misırlılarda güçlerini yenilemek amacıyla yapılan bir ritüelken, Romalılar ise gladyatörlerin öldükten sonra kanını içebilmek amacıyla birbirleriyle yarış halindeydiler (Yıldız, vd., 2006: 41). Günümüzde kan, kaynağı sadece insan olan ve elde edilmesinde başkaca hiçbir alternatifin bulunmadığı yegane tedavi aracıdır. Toplumdaki bütün bireyler tüm yaşamları boyunca gerek kendileri gerekse de aile ve yakın çevresi için kana ihtiyaç duymuştur. İlk kan nakli, 1665 yılında bir hayvandan diğer bir hayvana İngiliz Fizyolog Richard Lower tarafından gerçekleştirilmiştir. İngiliz kadın doğum uzmanı James Blundell ise 19. YY.'ın başlarında insandan insana kan naklini yapan kişi olmuştur. Son yıllarda tıp ve teknoloji alanında çok büyük ilerlemeler kaydedilmesine rağmen kanın yerine ikame edilebilecek herhangi bir madde bulunamamıştır (Hablemitoğlu vd., 2010:68). Kan ihtiyacı birçok ameliyat ve tedavide kullanılmaktadır. Örneğin; trafik kazalarında 5-10 litre, karaciğer naklinde 20-100 ünite, kalça ameliyatlarında 4-6 ünite, mide kanamalarında 3-20 ünite, omurga ameliyatlarında 6-10 ünite, böbrek naklinde 5-10 ünite, yenidoğan kan uyuşmazlığında 1-2 ünite, By-pass ameliyatlarında 4-8 ünite ve bazı hastalıklarda ise 200-250 ünite ortalama kana ihtiyaç vardır. Ayrıca kanser hastaları için her ay 1-3 ünite, kan hastalıkları olanlarda (talasemi, lösemi vb) her ay 1-5 ünite, diyaliz hastalarında her ay 1-3 ünite ortalama kana ihtiyaç vardır (Çoksak, 2017).

Kök hücreler, belli hücrelere dönüşebilen ve kendini yenileme yeteneği olan hücrelerdir. Vücudumuzdaki hücrelerin birçoğunun kendini yenileme yeteneği çok zayıftır ve bu hücreler farklılaşmıştır. Kök hücreler ise farklılaşmayan hücrelerdendir ve gerektiğinde diğer hücrelere dönüşebilmektedir. Herhangi bir uyarıcı olmadığında uzun yıllar farklılaşmadan kalabilirler. Kök hücre naklinde HLA denilen bir kişinin herhangi bir kişiye ne kadar uyum sağladığını gösteren doku grubu uyumluluğuna bakılmaktadır. Kalıtsal bir doku tipi olan HLA için öncelikle kişinin kardeşleri ve varsa ikizi eşleşme ihtimali en yüksek olan kişilerdir. Eğer ailede eşleşme söz konusu değil ise akraba olmayan kişiler arasında tarama yapılmaya başlanır. HLA doku tipinin eşleşmesi ile bağışçının hasta için en uygun kişi olduğu belirlenir. HLA doku tipinin eşleşmesi aynı zamanda en iyi naklin oluşmasına imkan tanıyacaktır (Türk Kızılayı Türkök Kök Hücre, 2019). Kök hücre tedavisi birçok önemli hastalığın çaresi olarak görülmektedir. Bunlar (Türk Kızılayı, 2019):

- Kemik iliği kanserleri,

- Çeşitli organ kanserleri,

- Kalitsal anemiler,

- Lenfomalar,

- Kalıtsal metobolik hastalıklar, 
- Akdeniz anemisi,

- Plazma hücre hastalıkları,

- Kalıtsal ve doğumsal kan hastalıkları,

- Kalıtsal metobolik hastalıklar,

- Kemik iliğinin çalışmadığı durumlar,

- İmmün yetersizlikleridir.

Kan ve kök hücre bağışı halkın sağlığı açısından gerekli olduğu halde birçok kişinin farklı nedenlerle yapmadığı/yapamadığı erdemli mallar arasında yer almaktadır. Çok sayıda fayda sağlamasına rağmen bireyler bilgi yetersizlikleri, zaman kısıtı vb. gibi birçok nedenle kan ve kök hücre bağışı yapmamakta, ilgili ürünler eksik üretilen mal ve hizmetler grubuna girmektedir. Bütün ülkelerde kan ve kök hücre bağışının özendirilmesi konusunda devletler önemli görevler üstlenmektedir.

\section{NEDEN KAN VE KÖK HÜCRE BAĞIŞI YAPILIR?}

Kan bağışı yapmak sadece tıbbi bir konu değil aynı zamanda sosyoloji ile de yakından ilişkilidir. Bağışçıların özelliklerini ilk olarak İngiliz Richard Titmus yapmış ve durumu 1970 yılında yayınladığı "Hediye İlişkisi" kitabında anlatmıştır. Kitapta kan bağış̧ıısı, 8 farklı özellikte incelenmiştir (Hablemitoğlu vd., 2010:69). Birinci tip paralı bağışçıdır ve herhangi bir tutar karşılığında kanını satmaktadır. İkinci tip herhangi bir para ya da ödül almak için düzenli olarak kanını satan profesyonel bağış̧̧ıdır. Üçüncü tip normal şartlarda kanını satan ancak para olmasa da kanını verebilecek olan yönlendirilmiş bağış̧̧ıdır. Dördüncü tip kendisinin kullandığı kan için kendisinden para alınması durumunda ilgili parayı ödememek ya da ödediği parayı geri alabilmek amacıyla kanını veren sorumluluk bedeli bağış̧̧ısıdır. Beşinci tip sonraki zamanlarda kendisine ya da yakın çevresine kan bulabilmek amacıyla belli aralıklarla kan veren aile kredisi bağışlayıcısıdır. Altıncı tip sosyal konumundan dolayı kan bağış olayını red edemeyen zorunlu bağış̧ıııı. Yedinci tip, kan bağışı yaptığında para dışındaki kendisine sunulan ödülü alan ödüllendirilmiş bağış̧̧ıdır. Sekizinci tip, para, bask1 ve herhangi bir ödül olmaksızın tamamen kendi özgür iradesiyle kanını bağışlayan bireydir. Kan bağış̧⿻ısı birey tutum, davranış, değer, inanç ve yönelim gibi davranışlara bağlı olarak karar vermektedir. Fishbein ve Ajzen (1974)'in nedenli eylem teorisine göre bireylerin kan bağışlayıp, bağışlamaması hali hazırdaki ya da gelecekteki amaçlarına göre belirlenmektedir. Dolayısıyla kan bağışına ilişkin bütün davranışlar; beklenti, değer ya da inanç fonksiyonu olarak ortaya çıkmaktadır. Sonraki süreçte planlı davranış teorisi olarak adlandırılan bu teori davranışların kökenini belirlemeye çalışmaktadır. Daha sonraları teori Ajzen tarafından düzenlenmiş ve davranışları üç faktörün tetiklediği belirtilmiştir. Bunlar öznel norm, kişisel tutum ve algılanan davranış kontrolüdür (Mercan, 2015:1).

Kök hücre bağış̧̧ıları benzer sebeplerle kök hücre bağışında bulunabilirler. Gönüllü kan bağışı yapan birçok kişinin aynı zamanda kök hücre bağışçısı olabileceğine inanılmaktadır. Fakat kök hüre bağışında prosedür çok daha fazladır. 18-50 yaş aralığındaki sağlıklı kişiler Gönüllü Kök Hücre Bağış̧̧ısı Bilgilendirme ve Onay Formunu doldurup imzalayarak resmi olarak bağış̧̧ı olurlar. Kan grubunun belirlenmesi ve enfeksiyon hastalıkları için 3 tüp kan alınır. Herhangi bir enfeksiyon hastalığı çıkmadığı takdirde doku tipinin ortaya çıkarılması için alınan kanlar, TÜRKÖK Doku Tiplendirme Laboratuvarı'na gönderilir ve test sonuçları Kemik İliği Bankası'na aktarılır. TÜRKÖK taramaları sonucunda bir hastaya ilişkin en iyi bağışçının, kök hücre bağışlamasını düşünen ilgili kişi olduğu düşünüldüğünde Kızılay 
yetkilisi tarafından aranılıp var olan hastayla doku uyumu için tekrar kan alınmakta TÜRKÖK Doku Tiplendirme Laboratuvarı'na gönderilmektedir. Hastadan alınan örneklerle kök hücre bağışçısının örnekleri uyum sağladığında Kızılay yetkilisi bağışçıyı aramakta ve nakil gününü ve bağışta kullanılmak üzere hastanın doktorunun, periferik kök hücre mi yoksa kemik iliği mi tercih ettiği bilgisini paylaşmaktadır. Sonuçta bağışçının sağlık tetkikleri yapılarak bağış gerçekleşir. Bağış ortalama 4-6 haftalık bir zamanda ve toplamda 20-30 saatlik bir zaman dilimini almaktadır (Türk Kızılayı, 2019). Bu organizasyonu gerçekleştirenler Kızılaya bağlı TÜRKÖK’ün yanı sıra; İstanbul Üniversitesi Tıp Fakültesi Kemik İliği Bankası (TRIS) ve Ankara Üniversitesi Tıp Fakültesi Akraba Dışı Doku ve Kordon Kanı Bankası (TRAN) ve bu kuruluşların bağlı olduğu Bone Marrow Donors Worldwide (BMDW) ve World Marrow Donor Association (WMDA) kuruluşları sayılabilir (Bulut, 2016: 36-37). Kök hücre bağışının daha zahmetli, uzun ve prosedürünün çok olması, kan bağışındaki duyarlılığın kök hücre bağışında gelişmemesi, kök hücre bağışçılarının sayısının çok az olmasına sebebiyet vermektedir. Kök hücre bağışı konusunda duyarlılığı olanlar daha çok kendi yakın çevresinde benzeri hastalıklara sahip olan kişilerdir.

\section{TÜRKIYYE'DE KAN VE KÖK HÜCRE BAĞIŞI DÜZEYİ}

Kan bağışı konusunda Türkiye diğer gelişmiş ülkelere göre oldukça geri kalmıştır. Yıldız, vd.,'nin 2006 yılında yaptıkları çalışmaya göre Türkiye'de nüfusun \%1,5'i düzenli bağışçı iken bu rakam gelişmiş ülkelerde $\% 5$ düzeylerindedir (Yıldız, vd., 2006: 54). Ülkemizde 2018 yılı verilerine göre toplam 2.571.482 ünite kan bağışı yapılmış ve bunun \%57'si düzenli bağışçılardan sağlanmıştır. Düzenli bağışçıların toplam nüfus içindeki oranı yaklaşık \%1,8 düzeylerindedir.

Tablo 1. 2004-2018 Yılları Arazı Kan Bağışı Sayısı

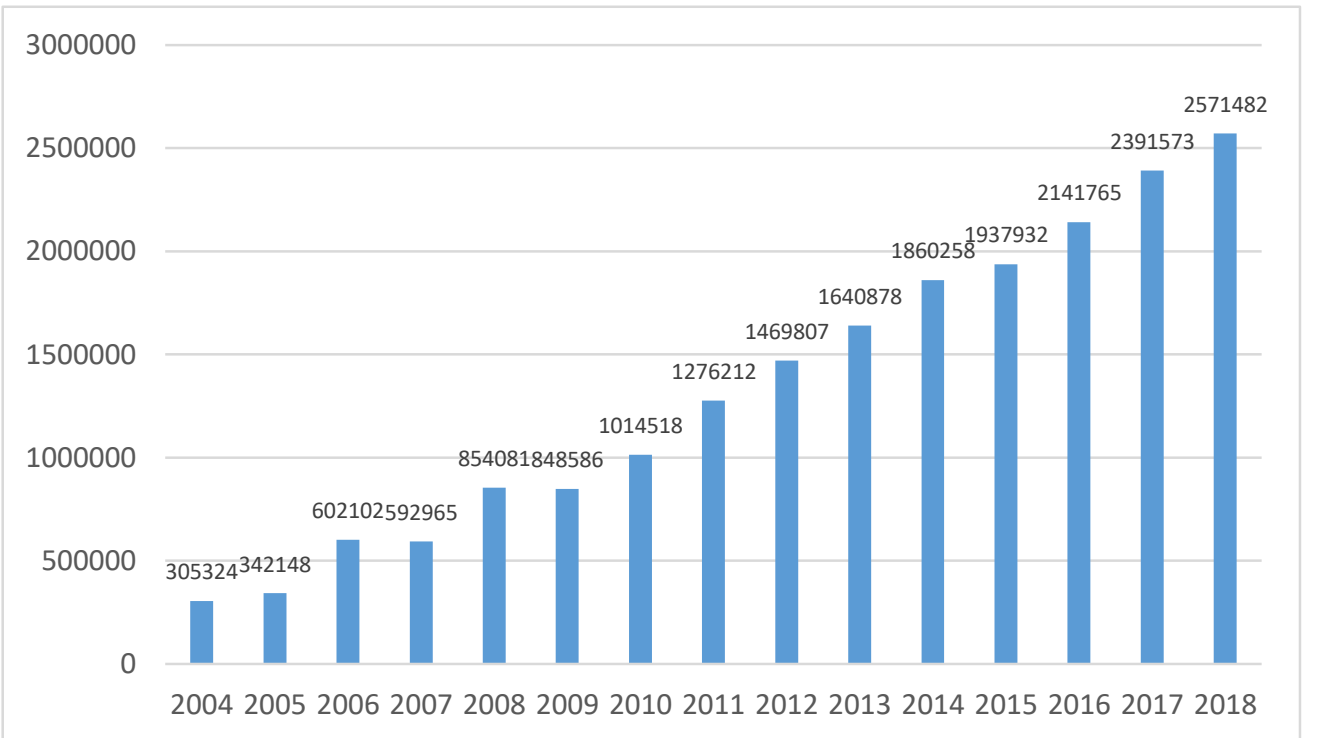

Kaynak: (Kan Hizmetleri Genel Müdürlüğü, 2018:66). 
Tablo 1'de 2004-2018 yılları arası kan bağışı sayıları verilmektedir. 2004 yılında 305.324 ünite kan bağışı yapılmışken bu rakam 2010 yılında 1.014 .518 üniteye yükselmiştir. 2010 yılındaki bağışın \%30’u düzenli kan bağışçılarından sağlanmıştır. 2018 yılında 2.571 .482 ünite kan bağışı yapılmış, bunun \%57'si düzenli kan bağışçılarından elde edilmiştir. Düzenli kan bağışçı sayısı da yıllar itibariyle artmaktadır. 2004 yılından 2018 yılına bağışlanan kan ünitesinde \%742'lik bir artış sağlanmıştır. Türk Kızılayı tüm ülke çapında 3500'e yakın uzman çalışanı ve 60 yılı aşkın birikimiyle 2018 yılı itibariyle toplam kan ihtiyacının \%86’sını karş1lamıştır (Kan Hizmetleri Genel Müdürlüğü, 2018:66-76).

Türk Kızılayı’nın 2016-2020 Stratejik Planında temel amaç; “..... toplumun kan ihtiyacında sürdürülebilir model olmak" kavramı tanımlanmış ve temel amaca yönelik dört stratejik hedef belirlenmiştir. Bunların en önemli ikisi; toplanan kanın \%60’ının düzenli bağışçılardan sağlanması, TÜRKÖK programı kapsamında kök hücre donörü bulunmasıdır. Bu sayede ülkemizde ve dünyada kan ve nakil bekleyen birçok kişiye ulaşılacaktır (Türk Kızılayı, 2016:10).

2018 yılı içerisinde Sağlık Bakanlığı tarafindan kök hücre bağışçı sayısı 80 bin olarak belirlenmiş, 27 Kasım 2018'de rakam revize edilerek 110 bine çekilmiştir. 2019 yılı hedefi olarak da 125 bin bağışçı hedeflenmiştir. 2018 yılı itibariyle 129.704 kök hücre bağışçısı kazanılmış, 110.000 bağışçının HLA numuneleri Doku Laboratuvarına gönderilmiştir (Kan Hizmetleri Genel Müdürlüğü, 2018:18).

Tablo 2. 2015-2018 Kök Hücre Nakil Sayısı

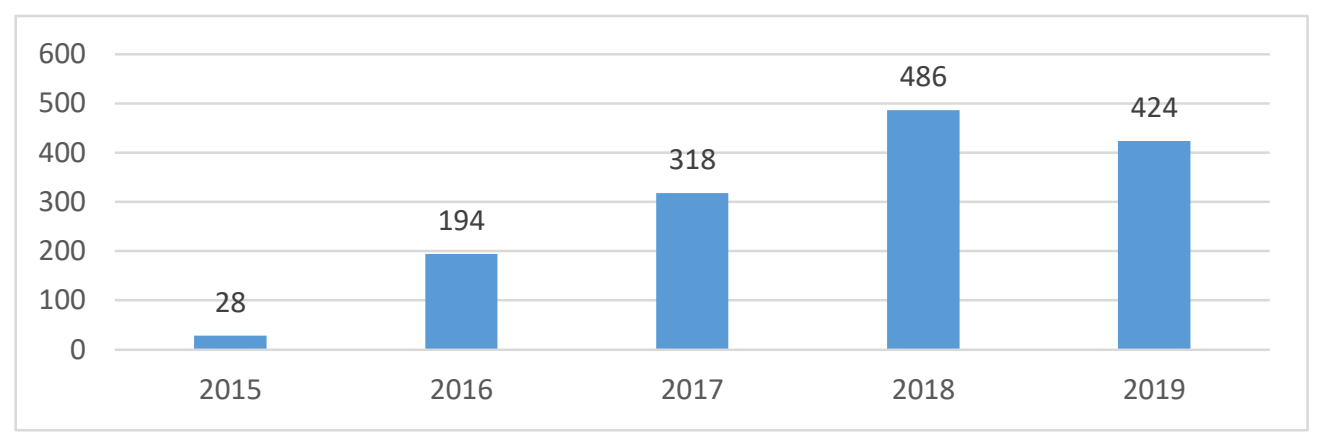

Kaynak: (Koca, 2019).

Tablo 2'den de görüleceği üzere TÜRKÖK projesinin hayata geçirilmesiyle 2015'te 28, 2016'da 194, 2017'de 318, 2018'de 486, 2019 yllının ilk 9 ayında ise 424 kök hücre, 779 yetişkin ve 671 pediyatrik olmak üzere toplamda 1450 hastaya nakledilmiştir. Ayrica 94 yabancı hasta Türkiye'ye gelerek kemik iliği nakli olmuştur (Koca, 2019). Kan ve kök hücre bağışıyla ilgili sürekli yapılan kampanyalarla bağış düzeyi her yıl artmaktadır.

\section{6. ÜLKEMIZDE KAN VE KÖK HÜCRE BAĞIŞININ EKSİKLİ̆̆İ}

Ülkemizdeki ortalama yıllık kan ihtiyacı 2.400.000 ünite civarlarındadır (Çoksak, 2017). Yapılan çalışmalarda ülkemizde insanların birçoğunun kan ve kök hücre bağışı konusunda duyarlı olmadıkları ve gereken özeni göstermedikleri ortaya konulmuştur. Kan ve kök hücre bağışıyla ilgili birçok yanlış anlayış ve inanç halen sürmektedir. Birçoğu bağışı yaptığında kendi sağlığının tehlikeye gireceğini düşünmekte, birçoğu ise bedava olarak bu işlemi 
yapmayacağını ya da sadece ailesinden birine kan ve kök hücre bağışı yapabileceğini belirtmektedir (Daştan, vd., 2013:27).

Kan yerine başka bir madde kullanılamadığından dolayı kan sürekli bir ihtiyaçtır. Teknolojideki tüm gelişmelere rağmen kan bileşenlerinin saklama süresi sınırlıdır. Örnek vermek gerekirse alyuvarlar için 42 gün, kan pulcuklarında ise saklama süresi 5 gündür (Jankulavsa, vd, 2015:6). Bu sebeple kan bağışı sadece bir kere yapılan bir eylem değil sürekli yapılması gereken erdemli bir davranıştır. Kök hücreler ise çok özel hücrelerdir. Vücudun çoğu hücresi (deri ve kalp hücreleri gibi) özel bir görev için şartlanarak faaliyette bulunurken, kök hücre ise özel bir hücreye dönüşmek için uyarı alana kadar herhangi bir şartlanma olmadan görev icra eder. Bu açıdan özellikle çoğalabilme ve özelleşebilme vasıfları onları çok özel kılmaktadır (Sargın, 2003: 49).

Amerika'da her yıl 6,5 milyon, Almanya'da 3,5 milyon ve Japonya'da ise 2 milyon ünite tam kan bağışı alınmaktadır (Türk Kızılayı Kan Hizmetleri Genel Müdürlüğü, 2019). Daha önce de ifade edildiği üzere Türkiye, kan bağışı konusunda önemli başarılar elde etmiş, 2018 yılında yaklaşık 2,5 milyon ünite kan bağışı sağlamıştır. Fakat yapılan bağışlar yeterli değildir. Kök hücre naklinde ise akraba dışı vericilerin sayısı oldukça yetersizdir. 2018 yılında 129,704 kök hücre bağışçısı kazanılmış, bu da toplam nüfusun on binde 15,81 'i kadardır. Kızılay halen 13 Gönüllü Verici Merkezi ile kök hücre bağışlarının yapılmasını sağlamaktadır. Kök hücre bağışında en önemli sorunlardan biri bağış̧̧ıların dokularının hastalarla uyuşması durumunda son anda bağış yapmaktan vazgeçmeleridir. 2018 y1lı içerisinde 144 bağış̧̧ı çeşitli sebeplerle kök hücre bağışçısı olmaktan vazgeçmişlerdir. Son anda bağıştan vazgeçilmesi birçok etik problemini de beraberinde getirmektedir (Kan Hizmetleri Genel Müdürlüğü, 2018:19).

2018 yılındaki kan bağışlarının \%84'ünü erkekler yapmış, kadınlar ise toplam bağışın sadece \%16'sını gerçekleştirmişlerdir (Kan Hizmetleri Genel Müdürlüğü, 2018:71). Sağlıklı bir erkek senede 4 kere kan bağışı yapabilirken, sağlıklı bir bayan senede 3 kez kan bağış1 yapabilmektedir. Kızılay Başkanı Dr. Kerem Kınık kan bağışının sürekli artmasının sevindirici olduğunu fakat halen yeterli olmadığını belirtmektedir (Anadolu Ajansı, 2018). 2018 yılında toplam kan bağışının \%57'si düzenli bağışçılardan yapılmıştır fakat bu rakamın artırılması gerekir. Gelişmiş ülkelerde düzenli bağışçıların toplam bağışlar içindeki oranı $\% 80$ 'leri geçmektedir.

2018 yılı itibariyle kök hücre bağışçılarının \%63,6'sı 18-35 yaş aralığında, \% 51'i ise aynı zamanda kan ve/veya trombosit aferezi bağışını gerçekleştiren kişilerden oluşmaktadır. Bağışların \%59'u erkekler, \%41'i ise kadınlar tarafından yapılmıştır. 2018 yılında 486 bağışçıdan kök hücre toplama işlemi tamamlanmıştır. Yapılan işlemlerin 10 tanesi yurt dişında bulunan hastalar içindir (Kan Hizmetleri Genel Müdürlüğü, 2018:17-18). TÜRKÖK projesiyle kök hücre bağışları artmakta ise de yapılan bağış miktarı yetersizdir.

\section{KAN VE KÖK HÜCRE BAĞIŞININ TEŞVIIKİ}

5624 Sayıl1 Kan ve Kan Ürünleri Kanunu'nun 3. Maddesinin B Bendine göre; “Kan, kan bileşenleri ve ürünlerinin temininde karşılıksız ve gönüllü bağış esastır. Ancak malî karşılık anlamına gelmeyecek şekilde kan bağışçısını teşvik edici uygulamalar müstesnadır” (5624 Sayılı Kan ve Kan Ürünleri Kanunu, 2007). 
Temel amaç kan bağışı yapanların bu eylemi gönüllü ve sürekli olarak yapmalarıdır. Bununla birlikte bağış yapanlara küçük hediyeler verilmesi onları teşvik etmektedir. Verilen özendirici ödüllerde amaç kan bağışını teşvik gibi görünse de uygulama, yapılan çok özel davranışa karşı bir teşekkürdür. 2018 yılında 250.000 adet kan gruplu anahtarlık, 20.000 adet knor çorba ve 66.000 adet çorba kasesi bağışçılara verilmiştir (Kan Hizmetleri Genel Müdürlüğü, 2018:45).

Kök hücre bağışçısının artırılması hususunda kök hücre bağışçılarına hatırlatma SMS'leri gönderilmiştir. Özellikle daha önce kök hücre bağışında bulunmamış 20-35 yaş aralığında olanlara SMS'ler atılmıştır. Kazanılmış kök hücre bağışçılarına kök hücre e-bülteni gönderilmiştir. 6 Nisan 2018 tarihinde yapılan "TÜRKÖK 3. Hasta-Bağışçı Buluşma Etkinliğgi” kapsamında Sağlık Bakanı'nın katılımıyla iki yılını dolduran bağışçılar hastaları ile tanıştırılmıştır (Kan Hizmetleri Genel Müdürlüğü, 2018:16-18). Dini açıdan da bakıldığında kök hücre bağışının teşvikiyle ilgili Diyanet İşleri Başkanı Ali Erbaş Anadolu Ajansı'na verdiği röportajda; kök hücre naklinin bir tedavi olduğunu ve İslam Dinine göre tedavi olmayı teşvik eden çok sayıda hadis-i şerif bulunduğunu vurgulamış ve kök hücre naklinin dinen caiz olduğunu belirtmiştir. Erbaş, İslam Dinine göre bir insanın hayatını kurtarmanın bütün insanların hayatını kurtarmak gibi olduğunu, sadece embriyonik kök hücre dışında diğer kök hücrelerin bağışlanmasının caiz olduğunu ifade etmiştir (Erbaş, 2019).

\section{KAN VE KÖK HÜCRE BAĞIŞI YAPAN GERÇEK KİŞILLERE VERGİ INDDIRIMI SAĞLANMASI}

Vergilemenin mali amaçları olduğu kadar mali olmayan amaçları da söz konusudur. Mali olmayan amaçlardan en önemlilerinden biri de vergilemenin sosyal politika aracı olarak kullanılmasıdır. Vergi sisteminin sosyal politikalara duyarlığının artırılması durumunda sosyal politika amaçları ile vergilemenin amaçları birleşecek aksi durumda ise vergileme sosyal politikalarda eksikliğe ve probleme sebep olacaktır (Karabacak, 2012: 225). Vergilerin kullanılması ile sosyal politika uygulamalarında 3 farklı yol tanımlanabilir. Birincisi, vergilendirme sosyal politikaları fonlamak için kullanılan paraların artırılmasında kullanılabilir. Bu durum vergilerin yeniden dağıtıcı ve sosyal politikaların dağıtımsal etkisiyle ilgilidir. İkincisi, vergilendirme sosyal politikaların doğrudan bir aracı olarak kullanılabilir. Örneğin gelirin yeniden dağıtımı amacıyla bazı bireylere vergi indirimleri verilebilir. Üçüncü olarak vergilendirme rejimi sosyal politika hedeflerinde dolaylı etkiler oluşturabilir. Örneğin bireylerin vergilendirme rejimleriyle sosyal politika hedefleri çatışabilir (Boden, 2005:107).

Devletçe uygulanacak sübvansiyon ya da vergi politikasının sosyal politikanın bir aracı olarak doğrudan kullanılması konumuz dahilindedir. Buna göre vergi harcaması olarak ifade edilen vazgeçilen vergi gelirleriyle sosyal politika hedefleri sağlanmaya çalışılır. Nitekim Greeve (1994), vergi harcamalarıyla "gizli bir refah devleti" gibi sosyal politikaların oluşumu, dağıtımı ve finansmanı gibi bütün yönlerinin yeniden tasarlanabileceğini ifade etmektedir (Boden, 2005:113-116).

Hükümetler kamusal sağlık sistemlerini inşa etmek ve geliştirmek amacıyla sağlık sektörüne önemli teşvikler sağlamaktadır. Özel sağlık programları kamusal teşviklerden yararlanmakta, sağlığa yönelik özel mal ve hizmetlerin tüketimi devletçe desteklenmektedir. Avusturalya, Kanada, Amerika Birleşik Devletleri gibi birçok ülke özel sağlık sigortaları üzerine önemli vergi indirimleri getirmektedir (Ocke, 2018:2036). 


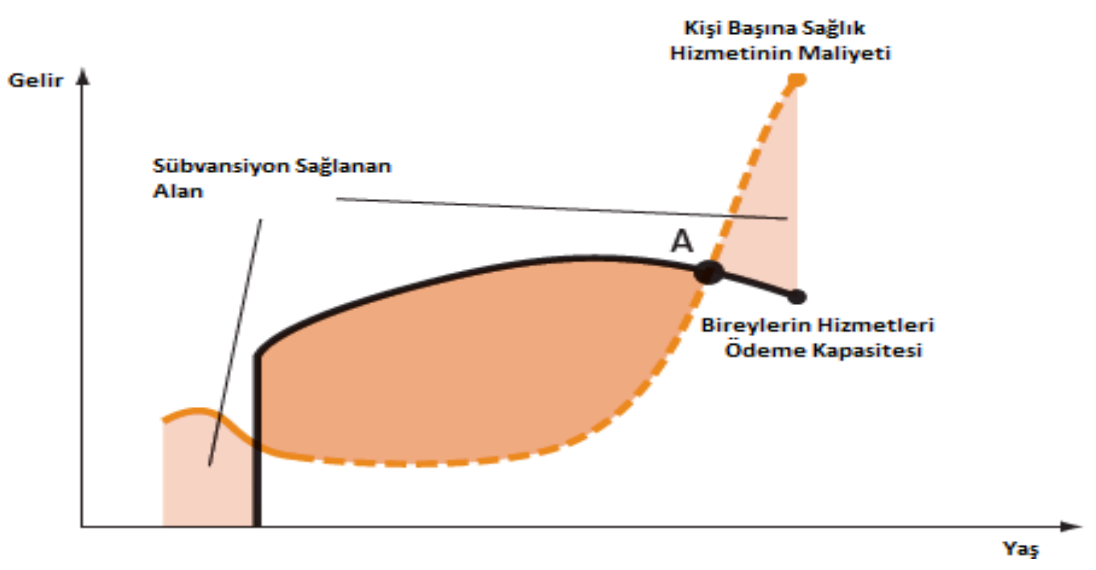

Şekil 1. Sağlık Hizmetlerinde Kamusal Sübvansiyon

Kaynak: (Gottret and Schieber, 2006:59).

Şekil 1'de sağlık hizmetlerinde verilen kamusal sübvansiyon alanları gösterilmektedir. Kişi başına sağlık hizmetleri maliyeti başlangıçta yüksekken yaş ilerledikçe düşmekte ve artan yaşlanmaya bağlı olarak yine artış göstermektedir. Bireylerin ödeme kapasitesi de gelire bağlı olarak belirli bir yaştan itibaren başlamakta, yaş ilerledikçe ödeme kapasitesi önce artmakta, yaşlılığa doğru ise azalma göstermektedir. Başlangıç durumu dediğimiz bebeklik ve çocukluk çağında bireylerin ödeme kapasitesi olmayacağı için devlet sübvansiyonu gerekmektedir. Yaşlılıkta ise (A noktasının sağında) kişi başına sağlık hizmetlerinin maliyeti, bireylerin hizmetleri ödeme kapasitesini aşacağı için devletçe sübvansiyon verilmesi gerekir. Verilecek sübvansiyonlar alt ve orta gelir gruplarını kapsamakta yüksek gelir gruplarını içermemektedir. Çünkü yüksek gelirliler her durumda sağlık hizmetlerinin finansmanını sağlamaktadırlar (Gottret and Schieber, 2006:59).

Türkiye'de sağlık hizmetleri kamu ve özel kesim tarafindan sunulmakta, hizmetlerin finansmanında başta vergiler olmak üzere özel sağlık sigortaları, primler, tıbbi tasarruflar ve cepten yapılan harcamalar kullanılmaktadır. Ülkemizde Bismark Modeli’ne göre belirli bir kesimi kapsayan sağlık sigortacılığının yanı sıra Beveridge Modeli olarak adlandırılan kamusal destek modeli de uygulanmakta ve hizmetlerin finansmanında özel harcamalardan da yararlanılmaktadır (Atasever, vd. 2014:4; Ağır ve Tıraş, 2018:645).

Çalışma kan bağışı ve kök hücre nakli konusunda alternatif bir öneri getirmektedir:

$\checkmark \quad$ Buna göre senede 3 kez kan bă̆ışı yapan gerçek kişilerin ilgili yıldaki toplam kazançlarının \%5'inin gider olarak düşülmesi,

$\checkmark \quad$ Ayrıca kök hücre bağlşçısı olan ve HLA doku tipinin uyuşması sonucu kök hücre naklini gerçekleştiren gerçek kişilerin ilgili yıldaki toplam kazançlarının \%30’unun gider olarak düşülmesi să̆lanmalıdır.

Bu sayede özellikle kan ve kök hücre bağışı konusunda bir farkındalık oluşturulacak ve kan ve kök hücre bekleyen birçok kişi için de bir umut 1şığı söz konusu olacaktır. Vergilemeyle eksta fiskal bir amacın gerçekleştirilmesi sağlanacaktır. 


\section{SONUÇ}

Kan geçmişten günümüze kadar bütün toplumlarda kutsal sayılan çok önemli bir tedavi aracıdır. Günümüz şartlarında teknoloji ne kadar ilerlese dahi kanın ikamesi olabilecek başkaca bir ürün geliştirilememiştir. Kan ve kök hücre bağışı bireylerin fedakarca yaptıkları önemli bir eylemdir. Kan bağışı sayıları ülkemizde yıllar itibariyle önemli artışlar gösterirken, kök hücre bağışında aynı başarı elde edilememiştir. Kök hücre bağışında ilgili hastaların akrabaları dışında verici sayısı çok azdır. Bağışçılar, dokuları hastalarla uyuşsa dahi son anda bağış yapmaktan vazgeçebilmektedirler. Sadece 2018 yılında 144 bağışçı bağış yapmaktan vazgeçmiştir. Kan ve kök hücre bağışı birçok kişiye hayat verecek erdemli birer davranıştır.

Yapılan çalışma öncelikle kan ve kök hücre bağışı konusunda mali araçlarla bir farkındalık oluşturmayı amaçlamaktadır. Vergilerin mali amaçları yanında mali olmayan amaçları da dikkate alındığında, kan ve kök hücre bağışı yapan gerçek kişilere vergi indirimi sağlanması, vergilerin sağlık alanındaki sosyal politika aracı olarak kullanılmasıdır. $\mathrm{Bu}$ indirimin yapılabilmesi için Kan ve Kan Ürünleri Kanunun 3. Maddesinde değişiklik şarttır. İlgili Kanunun 3. Maddesinde kan ve kan bileşenlerinin elde edilmesinde gönüllü ve karşıllksız bağışın esas olduğu fakat mali karşılık anlamına gelmeyecek kan bağışını teşvik eden uygulamaların istisna olduğu belirtilmiştir. Buna göre Kanun Maddesine devletçe yapılacak mali karşılık da dahil her türlü teşvik edici uygulamanın istisna olduğu eklenmelidir. Devlet uygulamanın başarısı için harcama ve vergiler dahil her türlü mali karşılık sunabilmelidir.

Günümüzde kan ve kan bileşimlerinden yapılan ve birçok kanser hastalığının tedavisinde kullanılan kan ilaçları tamamen ithal edilmekte ve çok yüksek fiyatlardan satılmaktadır. SGK bu ilaçların ödenmesinde önemli bir külfete katlanmaktadır. 19.05.2017 tarihinde Sağlık Bakanlığı, SGK ve Kızılay arasında "Plazma Ürünleri Elde Edilmesi Projesi Protokolü" hazırlanmış ve buna göre Kızılay ilgili ilaçların üretiminde kullanılacak kan ve kan bileşenlerinin hammadde sağlayıcısı olarak görevlendirilmiştir. SGK tarafından 15.09.2017 tarihinde ilaçların üretilip işletilmesini sağlayacak şirket belirlenmiş ve üretimi gerçekleştirecek şirketle "Plazma Ürünleri Elde Edilme Projesi" imzalanmıştır. Yine ilgili şirketle Kızılay arasında 12.06.2018 tarihinde "Plazma Temini Sözleşmesi ve Plazma Kalite Sözleşmesi” imzalanmıştır. Şirket tarafindan henüz bir üretim gerçekleştirilmese de üretimin başlamasıyla Kızılay plazma ürünlerin üretiminde kullanılacak olan kanların sağlanmasından da sorumlu olacaktır. Günümüzde bile tam olarak kan ihtiyacının karşılanmadığı düşünüldüğünde, ilerde çok daha fazla ünite kana ihtiyaç olduğu açıktır. Devletçe kan ve kök hücre bağışına yönelik vergi indirimleri ya da sübvansiyonların ekonomik değeri çok küçük olsa bile, uygulanacak politikalar farkındalığı artıracak ve çok sayıda kişinin hayatını kurtarmasını sağlayacaktır.

\section{KAYNAKÇA}

AĞIR, H. \& TIRAŞ, H. H. (2018). “Türkiye'de Sağlık Harcama Türlerinin Değerlendirilmesi”, Kahramanmaraş Sütçü İmam Üniversitesi Sosyal Bilimler Dergisi, 15(2): 643-670.

ANADOLU AJANSI, (2018). "Türkiye'de Düzenli Kan Bağış Oranı Yüzde 42'lerde”, <https://www.aa.com.tr/tr/turkiye/turkiyede-duzenli-kan-bagis-orani-yuzde-42lerde/1148728>, (22.09.2019). 
ATASEVER, M., KARACA, Z. \& ÖRNEK, M. (2017). “Türkiye'de Sağlık Harcamalarının Analizi”, SASAM Enstitüsü Analiz, 3(10), Ankara.

BODEN, R. (2005). "Taxation Research as Social Policy Research", Taxa $\neg$ tion: An Interdisciplinary Approach to Research”, Ed: Margaret Lamb, Andrew, Lymer, Judith Freedman, Simon James, Oxford University Press, New York.

BULUT, Alper, (2016). "Kemik İliği ve Kök Hücre Donörlerinin Bağış Sürecinin Son Safhasında Bağıştan Vazgeçmesi: Donör Hakkı Cinayet mi?”, Türkiye Biyoetik Dergisi, 3(1): 36-40.

ÇOKSAK, H. (2017). "Kan Bağışı”. $<$ http://www.antalyasm.gov.tr/DosyaIndir.ashx?Tip=1\&Id=68\&U=.pdf\&DosyaAd=KI ZILAY\%20HAFTASI\%20SUNUM>, (19.09.2019).

DAŞTAN, N. B., DAŞTAN, M. \& KIRANŞAL, N. (2013). "Sağlik Yüksekokulu Öğrencilerinin Kan Bağışına Yönelik Bilgi ve Tutumları", Kafkas Tıp Bilimleri Dergisi, 3(1): 27-32.

DURMUŞ, M. (2006). "Sosyal (Kamusal) Malların Yeniden Tanımlanması Gereği”, Ekonomik Yaklaşım, 17(59): 65-97.

ERBAŞ, A. (2019). "Kök Hücre Nakli ve Bağışına İlişkin Açıklama”, Diyanet Basın Merkezi, <www.diyanet.gov.tr>, (03.11.2019).

GOTTRET, B. \& SCHIEBER, G. (2006). “Collecting Revenue, Pooling Risk and Purchasing Services", Health Financing Revisited A Practioner's Guide, World Bank: Washington.

HABELEMITOĞLU, Ş., ÖZKAN, Y. \& YILDIRIM, F. (2010). "Bir Fedakâkarlık Örneği Olarak Kan Bağışı", Aile ve Toplum, Yı1: 11, 5(20) Ocak-Şubat-Mart: 67-77.

JANKULAVSA, M. A., YENICESU, İ. \& PİŞKİN, M. (2015). "Geleceğin Kan Bağışçılarının Kazanımı İçin Teknik Destek Projesi Öğretmen Kılavuzu”, AB Projesi,<http://ogm.meb.gov.tr/meb_iys_dosyalar/2016_10/18104656_ogretmen_kilav uzu_kan_bagisi.pdf>, (22.09.2019).

Kan Hizmetleri Genel Müdürlüğü, (2018). “2018 Faaliyet Raporu”, <https://www.kanver.org/Upload/Dokuman/Dosya/khgm-2018-21-08-201929913840.pdf>, (19.09.2019).

KARABACAK, Y. (2012). "Sosyal Politika Aracı Olarak Vergilemenin İşlevleri: Türkiye Örneğii”, İktisat Fakültesi Mecmuas1, 62(2): 223-252.

Kemik İliği Transplantasyonu, (2019). “Doku Uyumu (HLA) Uyumu Nedir?”, $<$ http://www.kemikiligi.org.tr/icerik.php?id=118\&alt_id=154\&tab=0>, (15.01.2020).

KİRMANOĞLU, H. (2017). “Kamu Ekonomisi Analizi”, Beta Yayınları: İstanbul.

KOCA, F. (2019). “Türkiye Kök Hücre Bağışında Dünyada İlk 10'a Yükseldi”, <https://www.memurlar.net/haber/856562/turkok-kok-hucre-bagisinda-dunyada-ilk10-a-yukseldi.html>, (03.11.2019). 
MERCAN, N. (2015). “Ajzen'in Planlanmış Davranış Teorisi Bağlamında Whistleblowing (Bilgi İfşası)”, Sosyal ve Beşeri Bilimler Dergisi, 7(2): 1-14.

OCKE, C. O. (2018), "Financial Sustainability of the Brazilian Health System And HealthRelated Tax Expenditures”, Ciência \& Saúde Coletiva, 23(6): 2035-2042.

SARGIN, D. (2003). "Kök Hücre ve Kök Hücre Tedavisi”, XXX. Ulusal Hematoloji Kongresi, <http://www.thd.org.tr/thdData/userfiles/file/kokhucre.pdf>, (03.11.2019).

TÜRKIYE CUMHURIYETİ SAĞLIK BAKANLIĞI, (2019). “TÜRKÖK’te 1000. Ve 1001. Nakil Gerçekleştirildi”, <https://www.saglik.gov.tr/TR,50733/turkokte-1000-ve-1001nakil-gerceklestirildi.html>, (15.01.2020).

TÜRK KIZILAYI TÜRKÖK KÖK HÜCRE, (2019). “Kök Hücre Bilgi”, <https://www.kanver.org/Upload/Dokuman/Dosya/09821300_kokhucrebilgi.pdf>, 801.11.2019).

TÜRK KIZILAYI, (2016). “2016-2020 Stratejik Plan”, <https://kizilay.org.tr/kurumsal/turkkizilay-stratejik-plani-2016-2020>, (19.09.2019).

TÜRK KIZILAYI KAN HIZMETLERİ GENEL MÜDÜRLÜĞÜ, (2019). "Dünyada ve Türkiye'de Kan Bankacılığı”, E-Kütüphane, <https://www.kanver.org/sayfa/ekutuphane/dunyada-ve-turkiye-de-kan-bankaciligi/43>, (22.09.2019).

TÜRK KIZILAYI, (2019). "Kök Hücre Bağışı”, <https://www.kanver.org/sayfa/kanhizmetleri/kok-hucre-bagisi/53> , (15.10.2019).

YILDIZ, Ç., GÜROL, E., KANIK, A., TİFTIK, N., SOLAZ, N., ASLAN, G., TEZCAN, S., SERIN, M., ERDEN, S., HELVACI, İ. \& OTAĞ, F. (2006). "Neden Kan Bağışlamıyoruz. Mersin İli’nde Yaşayanlarda Kan Bağışına Genel Bakış: Anket Çalışması" İnfeksiyon Dergisi, 20 (1), 41-55.

5624 Sayılı Kan ve Kan Ürünleri Kanunu, (2007). <http://www.resmigazete.gov.tr/eskiler/2007/05/20070502-1.htm>, (19.09.2019). 